\title{
Periodontitis, an Often-Overlooked Reservoir for Bacteria, in a Patient with Decubital Ulcer
}

\author{
Felix Evers ${ }^{1}$, Chongcong Wu ${ }^{2}$, Johanna Lönn ${ }^{3,4}$ and Fariba Nayeri ${ }^{1,4^{*}}$ \\ ${ }^{1}$ Division of Infectious Diseases, Department of Medical and Health Sciences, University Hospital, Linköping, Sweden \\ ${ }^{2}$ Maternal and Children Health Care Hospital of Zhuhai City, China \\ ${ }^{3}$ Department of Biomedicine, School of Health and Medical Sciences, Örebro University, Örebro, Sweden \\ ${ }^{4}$ The Institute of Protein Environment Affinity Surveys (PEAS Institut), Linköping, Sweden \\ *Corresponding Author: Fariba Nayeri, Department of Infectious Diseases, University Hospital in Linköping, Sweden, Tel: +46702080804; E-mail: \\ fariba.nayeri@lio.se
}

Received date: December 10, 2014, Accepted date: February 16, 2015, Published date: February 23, 2015

Copyright: ( 2015 Evers F, et al. This is an open-access article distributed under the terms of the Creative Commons Attribution License, which permits unrestricted use, distribution, and reproduction in any medium, provided the original author and source are credited.

\begin{abstract}
Antibiotic treatment of multiple resistant bacteria in biofilms might result in therapy failure and organ injuries. A case of infected decubital ulcer and severe periodontitis with growth of multiple resistant grampositive and -negative bacteria is presented. The patient was successfully treated after revisions with antibiotic directed against gram-positive bacteria.
\end{abstract}

\section{Description}

A non-smoking, wheelchair-using, 78-year-old woman with pronounced obesity, bilateral gonarthrosis, chronic ulcer, and heart failure was admitted to the medical clinic on $30^{\text {th }}$ April 2014 with severe respiratory insufficiency, acidosis, and arterial fibrillation. Blood tests revealed high C-Reactive Protein (CRP) levels and leucocytosis. Chest $\mathrm{X}$-ray showed stasis but no obvious signs of infection. She was treated empirically with intravenous cefotaxime and received anticoagulants, diuretics, ACE inhibitor, beta-blocker, and continuous positive airway pressure. She recovered within 2 weeks. However, the patient developed Clostridium difficile enteritis and decubital ulcer during her stay. She was discharged on $22^{\text {nd }}$ May with oral metronidazole.

On $28^{\text {th }}$ May, the patient was admitted and isolated in the department of infectious diseases with a $5 \mathrm{~cm}$ abscess at the crena ani. She received meropenem intravenously upon admittance and underwent surgical revision of necrotic fat and muscle tissue, resulting in a hole $5 \times 5 \times 10 \mathrm{~cm}$ with visible prespinal tissue. V.A.C.-pump wound dressing was initiated postsurgery. Cultures from sacral ulcer secretions revealed growth of resistant Escherichia coli (E. coli) (Amp C), extended-spectrum beta-lactamase-producing Klebsiella pneumoniae resistant to all antibiotics except colistin and gentamycin (ESBL-carba), Enterococcus faecalis (E. faecalis), multiresistant Enterococcus faecium, and multiresistant coagulase-negative Staphylococcus. Another surgical revision due to progress of necrotic tissue was performed after 3 days. The ulcer situation deteriorated, and on $2^{\text {nd }}$ June the V.A.C. pump was discontinued and antibiotic treatment was changed to intravenous vancomycin and metronidazole and local application of gel (containing 500,000 IU colistin+hepatocyte growth factor [HGF in $100 \mathrm{IU}$ antithrombin III Baxter] plus sodium chloride [1]) for 2 days, followed by Antithrombin III plus sodium chloride gel for 5 days. The wound dressing comprised sterile cotton compresses changed daily in the first 2 weeks. Ulcer bleeding, indicating development of regenerated tissue, was observed on $13^{\text {th }}$
June. Parameters indicating infection decreased, and muscle tissue filled the ulcer hole during the next 2 months. The patient received vancomycin infusions during the entire period. Cultures from the ulcer revealed no growth from $17^{\text {th }}$ June onward, and the patient was discharged on $27^{\text {th }}$ August with amoxicillin orally in 2 months. The ulcer is completely healed and the patient is feeling well in follow-up control in November 2014.

While searching for potential infectious foci, dental $\mathrm{x}$-rays (on $30^{\text {th }}$ July) revealed profound periodontitis. Several teeth were extracted, and cultures of extracted teeth, gingival secretion (on $31^{\text {st }} \mathrm{July}$ ), revealed growth of E. coli (Amp C) and E. faecalis with the same resistance profiles as the previous cultures from ulcer secretions, feces and inguinal area in May and June.

The coexistence of diverse gram-negative bacteria and $E$. faecalis in chronic ulcers may indicate the presence of biofilm [2]. Antibiotic therapy to treat gram-negative bacteria promotes growth of multiresistant bacteria in ulcers. Dental biofilms may serve as a reservoir of bacteria and antimicrobial resistance determinants [3]. Antibiotic-resistant bacteria, such as those that produce $\beta$-lactamase, are more prominent in periodontitis [4]. The toxic side effects of antibiotics that may be effective in in vitro susceptibility assays can cause organ damage and selection of resistant bacterial strains. Directed systemic therapy to eliminate adherent gram-positive bacteria, such as E. faecalis, together with ulcer revisions and circulation-promoting strategies, may effectively treat infection and heal chronic ulcers by destroying the biofilm. Thus, colonizing gramnegative bacteria may disappear without any directed treatment.

The ability of $E$. faecalis to adapt to different environments and acquire antibiotic and immune resistance by the formation of biofilms and transfer of resistance genes makes it a successful pathogen, and its presence may be advantageous for the survival and coexistence of other bacteria. E. faecalis may contribute to tissue breakdown at infected sites, and it is the most common bacterial isolate recovered after therapy failure [5].

The present case report, along with several other cases of difficultto-treat ulcers, highlight the importance of detecting the primary focus of infection, as it may be the original source. Also of critical importance is directed antibiotic treatment against the keystone bacteria of the biofilm, in order to deprive bacteria living in the biofilm community of protection and the benefits of symbiosis and to prevent selection of multiresistant bacterial strains (Figure 1). 
Citation: Evers F, Wu C, Lönn J, Nayeri F (2015) Periodontitis, an Often-Overlooked Reservoir for Bacteria, in a Patient with Decubital Ulcer. Clin Microbiol 4: 189. doi:10.4172/2327-5073.1000189

Page 2 of 2

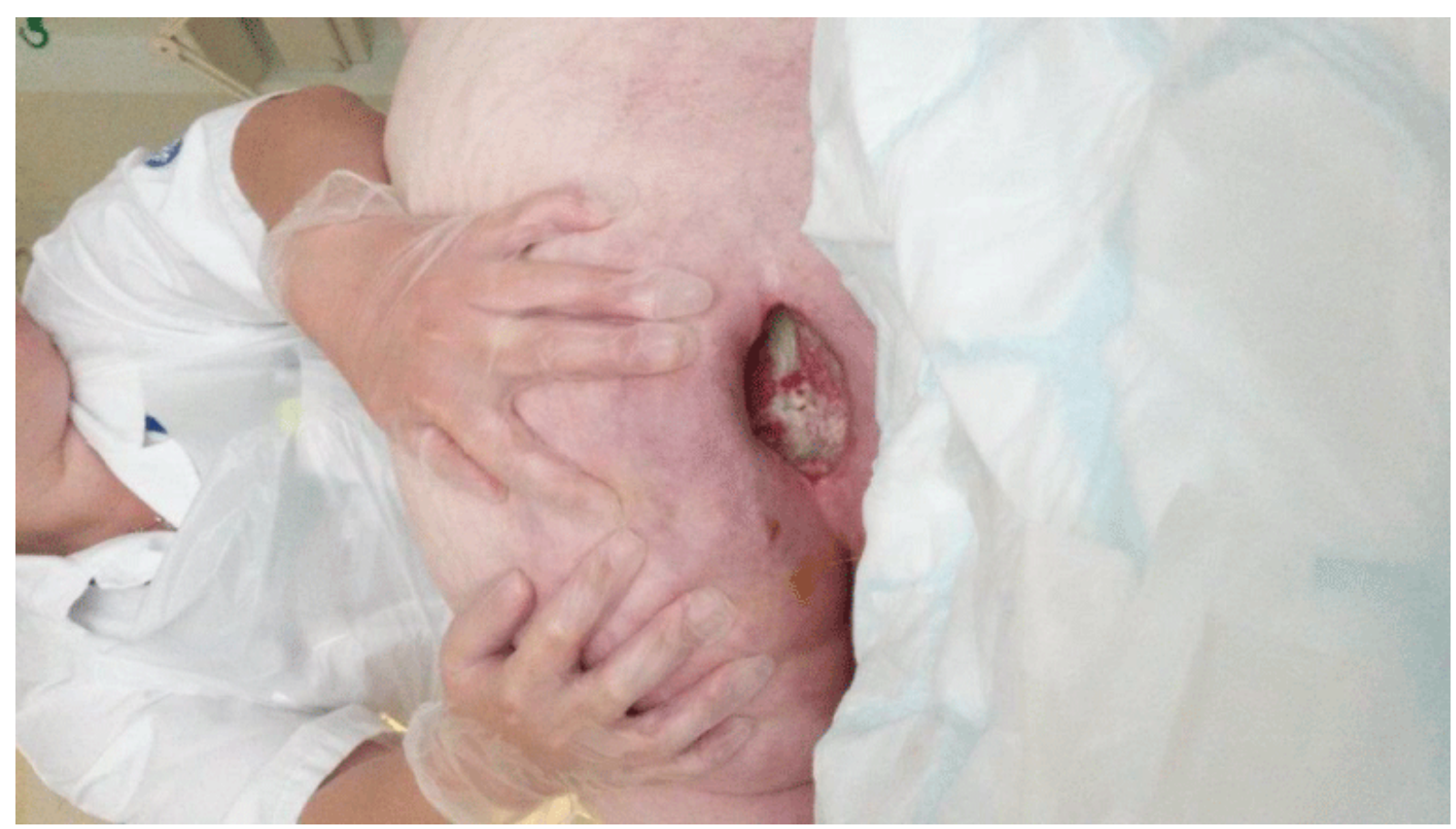

Figure 1: Decubital ulcer with growth of Enterococcus faecalis and several multiresistant strains. The picture was taken on $22^{\text {nd }}$ June

\section{References}

1. Lönn J, Almroth G, Brudin L, Nayeri F (2012) An Antithrombin II product containing biologically active hepatocyte growth factor may be beneficial in deep ulcer infections. Cytokine 60: 478-486.

2. Sun J, Sundsfjord A, Song X (2012) Enterococcus faecalis from patients with chronic periodontitis: virulence and antimicrobial resistance traits and determinants. Eur J Clin Microbiol Infect Dis 31: 267-272.
3. Kim SM, Kim HC, Lee SW (2011) Characterization of antibiotic resistance determinants in oral biofilms. J Microbiol 49: 595-602.

4. Rams TE, Degener JE, van Winkelhoff A (2014). Antibiotic resistance in human chronic periodontitis microbiota. J Periodontol 85: 160-169.

5. Rocas IN, Siqueira JF, Jr, Santos KR (2004) Association of Enterococcus faecalis with different forms of periradicular diseases. J Endod 30: 315-320. 